\title{
Copper, Manganese, Zinc, and Cadmium in Tea Leaves of Different Types and Origin
}

\author{
W. Podwika ${ }^{1} \cdot$ K. Kleszcz $^{1}$ (D) $\cdot$ M. Krośniak ${ }^{2} \cdot$ P. Zagrodzki $^{2}$
}

Received: 20 July 2017 / Accepted: 21 August 2017 / Published online: 2 September 2017

(C) The Author(s) 2017. This article is an open access publication

\begin{abstract}
Concentrations of selected metals (Cu, Mn, $\mathrm{Zn}, \mathrm{Cd})$ in tea leaves were investigated. Samples included black, green, and other (red, white, yellow, and oolong) teas. They were purchased on a local market but they covered different countries of origin. Beverages like yerba mate, rooibos, and fruit teas were also included in the discussion. Metal determinations were performed using atomic absorption spectrometry. In black teas, $\mathrm{Mn} / \mathrm{Cd}$ ratio was found to be significantly higher $(48,091 \pm 35,436)$ vs. green $(21,319 \pm 16,396)$ or other teas $(15,692 \pm 8393)$, while Cd concentration was lower $(31.4 \pm 18.3 \mu \mathrm{g} / \mathrm{kg})$ vs. other teas $67.0(67.0 \pm 24.4)$. Moreover, $\mathrm{Zn} / \mathrm{Cu}$ and $\mathrm{Cu} / \mathrm{Cd}$ ratios were, respectively, lower $(1.1 \pm 0.2$ vs. $2.2 \pm 0.5)$ and higher (1086 \pm 978 vs. $261 \pm 128)$ when comparing black teas with other teas. Intake of each metal from drinking tea was estimated based on the extraction levels reported by other authors. Contributions to recommended daily intake for $\mathrm{Cu}, \mathrm{Mn}$, and $\mathrm{Zn}$ were estimated based on the recommendations of international authorities. Except for manganese, tea is not a major dietary source of the studied elements. From the total number of 27 samples, three have shown exceeded cadmium level, according to local regulations.
\end{abstract}

K. Kleszcz

k_kleszcz@pwsztar.edu.pl

1 State Higher Vocational School in Tarnow, Mickiewicza 8 St., 33-100 Tarnow, Poland

2 Department of Food Chemistry and Nutrition, Medical College, Jagiellonian University, Medyczna 9 St., 30-688 Cracow, Poland
Keywords Tea $\cdot$ Cadmium $\cdot$ Zinc $\cdot$ Manganese $\cdot$ Copper $\cdot$ AAS

\section{Introduction}

Tea is an infusion prepared from Camellia sinensis leaves originating from China and some parts of India. Nowadays, this evergreen shrub is grown in many other countries, such as Japan, Indonesia, Sri Lanka, Kenya, and Vietnam. The conditions of growing tea shrub, e.g., location, climate, and soil, have an impact on the taste and properties of the final beverage [1].

Tea is the one of the most popular beverages in the world. Six types of tea are distinguished as follows: green, white, yellow, oolong (blue tea/semi-fermented tea), red, and black. These types differ in terms of oxidation level, color of leaves, and infusion. The oxidation level of tea determines the color of leaves and infusion and it depends on the way the fermentation was carried out. The most popular types of tea are the following: green tea, which preserves the properties of fresh leaves to the highest degree, and black tea, which is obtained after full fermentation of fresh leaves.

Among other components, tea leaves consist of tanning agents, alkaloids, amino acids, pigments, and trace amounts of mineral compounds. Trace elements present in tea leaves play an important role in human metabolism [2]. They can be released from leaves to the infusion. Thus, tea leaves may become the source of metals in human diet. Some of the metallic elements, such as copper, manganese, and zinc are essential for basic processes in the human body while others (like cadmium) are toxic. The main aim of our study was to determine the content of copper, manganese, zinc, and cadmium in tea leaves and to find out if there are any significant 
differences among the teas of different types and countries of their origin.

\section{Materials and Methods}

\section{Samples}

Tea samples $(n=27)$ were purchased on a local market in southern Poland. All samples were based on pure tea leaves, without additives or flavors. The set of samples included teas in the form of loose leaves as well as ground ones in tea bags. Samples were divided according to their type and country of origin. Among the samples, there were 12 samples of black tea, eight samples of green tea, two samples of red tea, two samples of white tea, two samples of oolong tea, and one sample of yellow tea. All details are given in Table 1.

\section{Methods}

Prior to the measurements, samples were dried for $2 \mathrm{~h}$ at $105^{\circ} \mathrm{C}$. Moisture content (calculated from the mass difference prior to and after drying) varied between $3.5 \%$ and $8.4 \%$. From each sample, approximately $0.5 \mathrm{~g}$ was taken for the analysis, and microwave-assisted wet digestion with ultrapure nitric acid was carried out. Certified Reference Material (CRM No. 7, Tea Leaves, National Institute of Environmental Studies) was included in the analysis (two samples) in order to provide quality assurance.

All determinations were performed using a Perkin-Elmer 5100 ZL atomic absorption spectrometer. Cadmium was determined using electrothermal atomization, while the rest of the elements were determined using flame technique.

\section{Statistical Approach}

For samples divided into three groups, black teas, green teas, and the others, the descriptive statistics were calculated. The comparisons between groups were performed using the Kruskal-Wallis test with the Dunn post hoc test. Statistical calculations were carried out using commercially available packages Statistica v. 12.5 (StatSoft, Tulsa, USA) and GraphPad InStat v. 3.05 (GraphPad Software, La Jolla, USA).

\section{Results and Discussion}

The results for CRM are listed in Table 2 and for tea samples in Table 3. Descriptive statistics for black, green, and other teas are given in Table 4.

\section{Copper}

Copper concentration in the samples varied from $9.1 \pm 0.2$ to $32.7 \pm 0.4 \mathrm{mg} / \mathrm{kg}$ (mean $18.7 \pm 6.3 \mathrm{mg} / \mathrm{kg}$ ). Street et al. [1] reported similar, though slightly higher values, between 9 and $65 \mathrm{mg} / \mathrm{kg}$ (for the group of 30 samples). Similar results were obtained by Ashraf and Mian [3] as well as by Narin et al. [4]. In our study, the mean concentration of copper in black teas was determined to be $21.3 \pm 6.9 \mathrm{mg} / \mathrm{kg}$ and for green teas $17.5 \pm 5.0 \mathrm{mg} / \mathrm{kg}$. These values were somewhat higher than those reported by Srividhya et al. [2] (14.34 $\pm 0.49 \mathrm{mg} / \mathrm{kg}$ for black teas and $11.28 \pm 0.08 \mathrm{mg} / \mathrm{kg}$ for green ones, respectively) but, at the same time, lower than reported by Gajewska et al. [5] (black teas $31.3 \pm 11.2 \mathrm{mg} / \mathrm{kg}$; green teas $20.0 \pm 5.9 \mathrm{mg} / \mathrm{kg}$ ). The common point is, however, that both Srividhya et al. [2] and Gajewska et al. [5] found higher copper concentrations in black teas than in the green ones, which were also noticed in the present work. Among all types, the highest levels of copper were found in the red and black teas. Copper concentrations in white $(15.5 \pm 0.1 \mathrm{mg} / \mathrm{kg})$ and oolong $(9.15 \pm 0.07 \mathrm{mg} / \mathrm{kg})$ teas found in our study are similar to the results of other researchers (Marcos et al. [6], McKenzie et al. [7], Xie et al. [8]), although higher results also have been reported (Malik et al. [9] 17.6-31.6 mg/kg for white and $15.1-25.8 \mathrm{mg} / \mathrm{kg}$ for oolong tea). Copper content in red teas $(22.0 \pm 0.7 \mathrm{mg} / \mathrm{kg})$ is comparable with the results of McKenzie et al. [7] (range 15-43 mg/kg).

\section{Manganese}

Manganese concentration in the samples varied from $457 \pm 4$ to $2210 \pm 35 \mathrm{mg} / \mathrm{kg}$ (mean $\pm \mathrm{SD} 962 \pm 388 \mathrm{mg} / \mathrm{kg}$ ). Similar results were published by Street et al. [1], where manganese concentration in 30 samples of different types of teas varied from 511 to $2220 \mathrm{mg} / \mathrm{kg}$. The authors did not notice a major difference between manganese concentration in black and green teas (nor they did for other elements: iron, zinc, and copper).

According to the type of the tea, the highest average concentration of manganese was observed for black teas (1094 $\pm 460 \mathrm{mg} / \mathrm{kg})$. This value is similar to the results from other studies $[2,5]$ which also have shown higher manganese concentration in black teas as compared to the green ones. According to Ashraf and Mian, Mn concentration in black tea samples studied by them was within the range of 448 $1072 \mathrm{mg} / \mathrm{kg}$ [3], while in the study of Narin et al., this range was $564-1082 \mathrm{mg} / \mathrm{kg}$ [4]. Both these studies provided results with lower maximum values than the ones observed in our study. Interestingly, tea leaves from Kenya contained apparently the highest concentration of manganese (maximum of $2210 \mathrm{mg} / \mathrm{kg}$ ) among all countries of the samples' origin. However, since only two samples from Kenya were analyzed, one should avoid making definite conclusions. Manganese 
Table 1 Details of samples' characteristics

\begin{tabular}{|c|c|c|c|c|}
\hline $\begin{array}{l}\text { Sample } \\
\text { no. }\end{array}$ & Type of tea & Form & Country of origin & Brand name \\
\hline 1 & Green & Loose leaves & China & Dynasty \\
\hline 2 & & & Sri Lanka & Sencha \\
\hline 3 & & & India & Assam OP \\
\hline 4 & & & Indonesia & Green Hills, Gunpowder Pearl \\
\hline 5 & & & Japan & Sencha \\
\hline 6 & & Tea bags & China & Oscar, Green Tea Bags, Yunnan \\
\hline 7 & & & Sri Lanka & Dilmah, Pure Green \\
\hline 8 & & & Vietnam/China & Packers Best \\
\hline 9 & Black & Loose leaves & China & Golden Dynasty \\
\hline 10 & & & Sri Lanka & Dimbula Uduwela \\
\hline 11 & & & India & Hattialli \\
\hline 12 & & & Vietnam & Vietnam \\
\hline 13 & & & Kenya & Green Hills, Kenya Pearl \\
\hline 14 & & & No data & Lipton \\
\hline 15 & & Tea bags & Sri Lanka & Jones Classic \\
\hline 16 & & & Kenya & Loyd, Black Sense, Kenya \\
\hline 17 & & & Argentina, Iran, Indonesia (mix) & Ulubiona \\
\hline 18 & & & No data & Assuan \\
\hline 19 & & & No data & Assam, Teekane \\
\hline 20 & & & No data & Minutka \\
\hline 21 & White & Loose leaves & China & Pai Mu Tan \\
\hline 22 & & & China & Shou Mei \\
\hline 23 & Red & Loose leaves & China & Pu-erh \\
\hline 24 & & Tea bags & China & Pu-erh \\
\hline 25 & oolong & Loose leaves & Taiwan & Formosa \\
\hline 26 & & & China & Tie Guan Yin Wangjia \\
\hline 27 & Yellow & Loose leaves & China & Yellow Tea \\
\hline
\end{tabular}

concentration in white $(1068 \pm 45 \mathrm{mg} / \mathrm{kg})$ and oolong $(968 \pm 26 \mathrm{mg} / \mathrm{kg})$ teas was similar to reported elsewhere (McKenzie et al. [7], Xie et al. [8]), although relatively low results can be found (Malik et al. [9] 293-479 mg/kg for white tea, which is, in general, low concentration, regardless of the type of tea). Manganese content in red teas $(860 \pm 183 \mathrm{mg} / \mathrm{kg})$ is comparable with the results of McKenzie et al. (range 615$1268 \mathrm{mg} / \mathrm{kg}$ ) [7].

Table 2 Results for Certified Reference Materials

\begin{tabular}{llcl}
\hline CRM & Element & Measured value $[\mathrm{mg} / \mathrm{kg}]$ & Certified value $[\mathrm{mg} / \mathrm{kg}]$ \\
\hline Sample 1 & $\mathrm{Mn}$ & $701 \pm 15$ & $700 \pm 25$ \\
Sample 2 & & $716 \pm 8$ & \\
Sample 1 & $\mathrm{Zn}$ & $32.3 \pm 0.2$ & $33 \pm 3$ \\
Sample 2 & & $31.2 \pm 0.7$ & \\
Sample 1 & $\mathrm{Cd}$ & $0.033 \pm 0.001$ & $0.030 \pm 0.003$ \\
Sample 2 & & $0.030 \pm 0.001$ & \\
Sample 1 & $\mathrm{Cu}$ & $6.8 \pm 0.2$ & $7.0 \pm 0.3$ \\
Sample 2 & & $6.9 \pm 0.4$ & \\
\hline
\end{tabular}

\section{Zinc}

Zinc concentration in all samples varied between $12.6 \pm 0.2$ and $45.5 \pm 0.1 \mathrm{mg} / \mathrm{kg}$. The mean value equaled $24.4 \pm 7.7 \mathrm{mg} / \mathrm{kg}$ and was in line with the results reported by Srividhya et al., $25.39 \pm 0.59 \mathrm{mg} / \mathrm{kg}$ for black teas and $26.39 \pm 0.92 \mathrm{mg} / \mathrm{kg}$ for the green ones [2]. Results published by Street et al. were higher $(21.5-75.2 \mathrm{mg} / \mathrm{kg}$ ) than in our study [1].

Our results of zinc concentration in green and black teas are similar to those reported by Srividhya et al. [2] as well as Gajewska et al. [5] and Narin et al. [4]. On the other hand, the mean value of zinc concentration in black teas given by Ashraf and Mian $(65.7 \pm 31.3 \mathrm{mg} / \mathrm{kg})$ was much higher than the one found by us, which was $(21.8 \pm 5.1 \mathrm{mg} / \mathrm{kg})$ [3]. In regard to white and oolong teas, zinc concentration found in our study $(29.6 \pm 6.5 \mathrm{mg} / \mathrm{kg}$ for white tea and $22.7 \pm 1.0 \mathrm{mg} /$ $\mathrm{kg}$ for oolong tea) are in line with other reports (McKenzie et al. [7], Xie et al. [8], Malik et al. [9]). Zinc content in red teas $(38.7 \pm 7.7 \mathrm{mg} / \mathrm{kg})$ is comparable with the results of McKenzie et al. (range 26-52 mg/kg) [7]. 
Table 3 Concentration of the studied metals in tea samples

\begin{tabular}{|c|c|c|c|c|c|c|c|c|}
\hline Sample no. & $\begin{array}{l}\mathrm{Cu} \\
{[\mathrm{mg} / \mathrm{kg}]}\end{array}$ & $\operatorname{RSD}[\%]$ & $\begin{array}{l}\mathrm{Mn} \\
{[\mathrm{mg} / \mathrm{kg}]}\end{array}$ & RSD [\%] & $\begin{array}{l}\mathrm{Zn} \\
{[\mathrm{mg} / \mathrm{kg}]}\end{array}$ & $\operatorname{RSD}[\%]$ & $\begin{array}{l}\mathrm{Cd} \\
{[\mu \mathrm{g} / \mathrm{kg}]}\end{array}$ & $\operatorname{RSD}[\%]$ \\
\hline 1 & 16.7 & 1.0 & 593 & 1.8 & 21.3 & 5.2 & 37 & 14 \\
\hline 2 & 15.1 & 2.2 & 746 & 1.2 & 25.2 & 0.2 & 64.3 & 1.6 \\
\hline 3 & 18.0 & 1.8 & 607 & 1.1 & 25.2 & 0.5 & 44.4 & 2.3 \\
\hline 4 & 26.6 & 1.8 & 457 & 0.80 & 18.8 & 1.2 & 14 & 14 \\
\hline 5 & 12.1 & 4.3 & 900 & 2.4 & 12.6 & 1.4 & 15.7 & 1.6 \\
\hline 6 & 22.6 & 0.4 & 582 & 1.6 & 28.7 & 1.8 & 28.2 & 4.3 \\
\hline 7 & 16.8 & 2.2 & 1590 & 1.7 & 23.4 & 0.7 & 129 & 0.07 \\
\hline 8 & 11.8 & 0.5 & 1035 & 1.5 & 17.8 & 2.4 & 153 & 5.3 \\
\hline 9 & 25.0 & 1.8 & 1080 & 2.8 & 29.1 & 0.7 & 34.7 & 1.9 \\
\hline 10 & 19.1 & 0.6 & 717 & 0.42 & 13.3 & 0.5 & 6.0 & 13 \\
\hline 11 & 32.7 & 1.2 & 626 & 2.2 & 26.5 & 0.5 & 26.3 & 3.6 \\
\hline 12 & 17.3 & 0.1 & 1180 & 1.7 & 21.1 & 2.4 & 42.0 & 0.05 \\
\hline 13 & 31.0 & 1.2 & 2210 & 1.6 & 25.9 & 0.8 & 64.3 & 7.0 \\
\hline 14 & 22.5 & 1.8 & 831 & 1.9 & 27.0 & 1.7 & 35.6 & 1.5 \\
\hline 15 & 30.9 & 1.0 & 561 & 4.1 & 26.3 & 0.2 & 13.0 & 12 \\
\hline 16 & 14.1 & 6.0 & 1020 & 2.0 & 20.0 & 1.8 & 34.5 & 8.8 \\
\hline 17 & 16.4 & 5.5 & 1290 & 2.6 & 17.9 & 4.1 & 59.9 & 3.5 \\
\hline 18 & 16.7 & 4.5 & 1620 & 2.3 & 14.7 & 5.8 & 28.8 & 5.6 \\
\hline 19 & 14.9 & 4.5 & 876 & 2.5 & 20.4 & 0.7 & 7.9 & 5.6 \\
\hline 20 & 15.2 & 2.1 & 1130 & 2.0 & 19.9 & 1.7 & 24.0 & 0.14 \\
\hline 21 & 15.4 & 1.3 & 1036 & 1.1 & 34.2 & 0.3 & 47.3 & 7.1 \\
\hline 22 & 15.6 & 7.0 & 1100 & 2.5 & 25.0 & 2.5 & 35.6 & 9.1 \\
\hline 23 & 22.7 & 2.1 & 990 & 2.8 & 31.8 & 3.7 & 58.5 & 5.8 \\
\hline 24 & 21.7 & 4.7 & 730 & 3.1 & 45.5 & 0.3 & 106 & 0.51 \\
\hline 25 & 9.2 & 5.3 & 949 & 3.4 & 22.0 & 0.6 & 89.7 & 1.9 \\
\hline 26 & 9.1 & 1.7 & 986 & 1.5 & 23.4 & 0.8 & 71.6 & 2.6 \\
\hline 27 & 14.6 & 7.6 & 541 & 1.1 & 42.4 & 0.8 & 60.4 & 1.2 \\
\hline
\end{tabular}

The highest concentrations of zinc were found in red and yellow tea samples. When referring to the country of origin, the teas from China had the highest zinc concentration while tea samples from other countries (except for Japan) had similar levels of this element.

\section{Cadmium}

Average cadmium concentration in all tea samples equaled $49 \pm 36 \mu \mathrm{g} / \mathrm{kg}$. However, concentration of this element was rather disparate among all studied samples. The highest $\mathrm{Cd}$ concentration $(153 \pm 8 \mu \mathrm{g} / \mathrm{kg})$ was found in sample no. 8-green tea (tea bag), while the lowest one $(6.0 \pm 0.8 \mu \mathrm{g} / \mathrm{kg})$ in sample no. 10 -black tea (leaves). These results are much lower than results shown by Ashraf and Mian [3] and Narin et al. [4] who found Cd concentration in black teas to be equal $1.1 \pm 0.5$ and $2.3 \pm 0.4 \mathrm{mg} / \mathrm{kg}$, respectively. Regarding oolong tea, our result $(80.6 \pm 12.8 \mu \mathrm{g} / \mathrm{kg})$ is very similar to the one presented by Marcos et al. $(82 \pm 9 \mu \mathrm{g} / \mathrm{kg}$; one sample only) [6].

Studies published by Gajewska et al. showed that an average $\mathrm{Cd}$ concentration was much higher for black teas $(426 \pm 506 \mu \mathrm{g} / \mathrm{kg})$ than for the green ones $(218 \pm 43 \mu \mathrm{g} / \mathrm{kg})$ [5]. Contrary to that, our results were in the opposite order; an average $\mathrm{Cd}$ concentration was $31.3 \pm 18.4 \mu \mathrm{g} / \mathrm{kg}$ for black teas and $60.3 \pm 52.8 \mu \mathrm{g} / \mathrm{kg}$ for the green ones. Therefore, not only was the tendency reversed, but also the values apparently differed. However, more recently, Srividhya et al. reported Cd concentration in green teas to be twice as high as for the black teas $(1.59 \pm 0.26$ and $0.89 \pm 0.10 \mathrm{mg} / \mathrm{kg}$, respectively), though this result is based on two samples only [2].

Among the tea samples studied by us, the lowest concentration of cadmium was found in black teas and the highest in red and oolong teas. When considering the country of origin, low $\mathrm{Cd}$ concentrations were found in teas from Japan and Indonesia while in the sample from Taiwan, it was relatively high. Table 5 shows comparison of our results with other researches. 
Table 4 Descriptive statistics for studied parameters in the samples; mean values with the same letter in upper index differ significantly

\begin{tabular}{|c|c|c|c|c|c|c|c|}
\hline Parameter & $N$ & Mean & Median & Min & Max & $\mathrm{SD}$ & Kurtosis \\
\hline \multicolumn{8}{|l|}{ Black teas } \\
\hline $\mathrm{Mn}(\mathrm{mg} / \mathrm{kg})$ & 12 & 1094.1 & 1047.9 & 561.2 & 2209.7 & 460.5 & 2.210 \\
\hline $\mathrm{Zn}(\mathrm{mg} / \mathrm{kg})$ & 12 & 21.8 & 20.8 & 13.3 & 29.1 & 5.1 & -1.061 \\
\hline $\mathrm{Cd}(\mu \mathrm{g} / \mathrm{kg})$ & 12 & $31.4^{\mathrm{a}}$ & 31.7 & 5.5 & 64.3 & 18.3 & -0.223 \\
\hline $\mathrm{Cu}(\mathrm{mg} / \mathrm{kg})$ & 12 & 21.3 & 18.2 & 14.1 & 32.7 & 6.9 & -1.203 \\
\hline $\mathrm{Mn} / \mathrm{Zn}$ & 12 & 53.3 & 52.3 & 21.3 & 109.7 & 25.9 & 0.691 \\
\hline $\mathrm{Mn} / \mathrm{Cd}$ & 12 & $48091^{\mathrm{b}, \mathrm{c}}$ & 32747 & 21532 & 129907 & 35436 & 2.116 \\
\hline $\mathrm{Mn} / \mathrm{Cu}$ & 12 & 56.2 & 63.5 & 18.1 & 96.8 & 24.9 & -0.950 \\
\hline $\mathrm{Zn} / \mathrm{Cd}$ & 12 & 1095 & 794 & 298 & 3022 & 882 & 0.758 \\
\hline $\mathrm{Zn} / \mathrm{Cu}$ & 12 & $1.1^{\mathrm{d}}$ & 1.1 & 0.7 & 1.4 & 0.2 & -1.546 \\
\hline $\mathrm{Cu} / \mathrm{Cd}$ & 12 & $1086^{\mathrm{e}}$ & 633 & 274 & 3453 & 978 & 2.046 \\
\hline \multicolumn{8}{|l|}{ Green teas } \\
\hline $\mathrm{Mn}(\mathrm{mg} / \mathrm{kg})$ & 8 & 814.3 & 676.5 & 457 & 1593.6 & 366.7 & 2.587 \\
\hline $\mathrm{Zn}(\mathrm{mg} / \mathrm{kg})$ & 8 & 21.6 & 22.3 & 12.6 & 28.7 & 5.1 & 0.021 \\
\hline $\mathrm{Cd}(\mu \mathrm{g} / \mathrm{kg})$ & 8 & 60.7 & 40.8 & 14.1 & 153 & 52.4 & -0.166 \\
\hline $\mathrm{Cu}(\mathrm{mg} / \mathrm{kg})$ & 8 & 17.5 & 16.8 & 11.8 & 26.6 & 5.0 & 0.183 \\
\hline $\mathrm{Mn} / \mathrm{Zn}$ & 8 & 40.5 & 28.8 & 20.3 & 71.3 & 21.5 & -1.807 \\
\hline $\mathrm{Mn} / \mathrm{Cd}$ & 8 & $21319^{\mathrm{b}}$ & 14821 & 6767 & 57174 & 16396 & 3.318 \\
\hline $\mathrm{Mn} / \mathrm{Cu}$ & 8 & 52.3 & 42.5 & 17.2 & 94.6 & 29.6 & -1.641 \\
\hline $\mathrm{Zn} / \mathrm{Cd}$ & 8 & 650 & 567 & 116 & 1335 & 435 & -1.165 \\
\hline $\mathrm{Zn} / \mathrm{Cu}$ & 8 & 1.3 & 1.3 & 0.7 & 1.7 & 0.3 & 1.235 \\
\hline $\mathrm{Cu} / \mathrm{Cd}$ & 8 & 594 & 428 & 77 & 1885 & 587 & 3.557 \\
\hline \multicolumn{8}{|l|}{ Other teas } \\
\hline $\mathrm{Mn}(\mathrm{mg} / \mathrm{kg})$ & 7 & 903.9 & 985.6 & 541.2 & 1096.7 & 196.9 & 0.815 \\
\hline $\mathrm{Zn}(\mathrm{mg} / \mathrm{kg})$ & 7 & 32.1 & 31.8 & 22.0 & 45.5 & 9.3 & -1.476 \\
\hline $\mathrm{Cd}(\mu \mathrm{g} / \mathrm{kg})$ & 7 & $67.0^{\mathrm{a}}$ & 60.4 & 35.6 & 106 & 24.4 & -0.427 \\
\hline $\mathrm{Cu}(\mathrm{mg} / \mathrm{kg})$ & 7 & 15.5 & 15.4 & 9.1 & 22.7 & 5.4 & -1.166 \\
\hline $\mathrm{Mn} / \mathrm{Zn}$ & 7 & 31.3 & 31.2 & 12.8 & 43.8 & 12.8 & -1.449 \\
\hline $\mathrm{Mn} / \mathrm{Cd}$ & 7 & $15692^{\mathrm{c}}$ & 13768 & 6865 & 30836 & 8393 & 0.517 \\
\hline $\mathrm{Mn} / \mathrm{Cu}$ & 7 & 66.2 & 67.2 & 33.6 & 108.2 & 30.5 & -1.563 \\
\hline $\mathrm{Zn} / \mathrm{Cd}$ & 7 & 525 & 543 & 246 & 723 & 196 & -1.815 \\
\hline $\mathrm{Zn} / \mathrm{Cu}$ & 7 & $2.2^{\mathrm{d}}$ & 2.2 & 1.4 & 2.9 & 0.5 & -0.737 \\
\hline $\mathrm{Cu} / \mathrm{Cd}$ & 7 & $261^{\mathrm{e}}$ & 242 & 103 & 438 & 128 & -1.543 \\
\hline
\end{tabular}

${ }^{\mathrm{a}} p<0.05 ;{ }^{\mathrm{b}} p<0.05 ;{ }^{\mathrm{c}} p<0.01 ;{ }^{\mathrm{d}} p<0.001 ;{ }^{\mathrm{e}} p<0.01$
Comparing black and green teas, $\mathrm{Mn} / \mathrm{Cd}$ ratio was found to be significantly different between these two groups. When comparing black teas to the others, four parameters showed significant differences: $\mathrm{Cd}$ concentrations, $\mathrm{Mn} / \mathrm{Cd}, \mathrm{Zn} / \mathrm{Cu}$, and $\mathrm{Cu} / \mathrm{Cd}$ ratios. Further studies, including more tea samples, are needed to establish if there is such a general trend for these groups of teas.

Since black tea undergoes full fermentation during production, it seems that this process can affect the content of the metals (e.g., removing the metals by rinsing them out from the leaves; the degree of this removal can vary for each metal). Besides this, the content of the given metal in tea leaves obviously depends on its content in the tea plantation soil.

\section{Daily Intake Estimation}

Daily intake of all determined metals with consumed tea infusion for black and green teas was estimated. It was based on the assumptions that the daily consumption of tea is three cups and each one is prepared using $1.5 \mathrm{~g}$ of tea leaves. Extraction degrees for each element were taken from the report of Gajewska et al. [5]. Recommended daily intake for Mn, Zn, and $\mathrm{Cu}$ was taken from the Dietary Reference Intakes [10]. In addition, the European Union Population Reference Intake for adults is given for comparison [11].

Estimated daily intakes together with the recommendations mentioned above for black and green tea are listed in Table 6 . 
Table 5 Comparison of results of this work with reported by other authors

\begin{tabular}{|c|c|c|c|c|c|c|c|}
\hline & & This work & Street et al. $(2006)^{\mathrm{a}}$ & Narin et al. (2004) & $\begin{array}{l}\text { Ashraf and } \\
\text { Mian (2008) }\end{array}$ & $\begin{array}{l}\text { Srividhya et al. } \\
\text { (2011) }\end{array}$ & $\begin{array}{l}\text { Gajewska et al. } \\
(2000)\end{array}$ \\
\hline \multirow[t]{5}{*}{ Green tea $($ mean $\pm \mathrm{SD})$} & Number of samples & 8 & 13 & - & - & 1 & 14 \\
\hline & $\mathrm{Mn}[\mathrm{mg} / \mathrm{kg}]$ & $814 \pm 367$ & $1092 \pm 440$ & - & - & $508 \pm 44$ & $663 \pm 168$ \\
\hline & $\mathrm{Cu}[\mathrm{mg} / \mathrm{kg}]$ & $17.5 \pm 5.0$ & $23.6 \pm 5.8$ & - & - & $11.28 \pm 0.08$ & $20.0 \pm 5.9$ \\
\hline & $\mathrm{Zn}[\mathrm{mg} / \mathrm{kg}]$ & $21.6 \pm 5.1$ & $47.2 \pm 15.8$ & - & - & $26.39 \pm 0.92$ & $45.7 \pm 16.1$ \\
\hline & $\mathrm{Cd}[\mu \mathrm{g} / \mathrm{kg}]$ & $60.3 \pm 52.8$ & - & - & - & $1.59 \pm 0.26$ & $218 \pm 43^{\mathrm{b}}$ \\
\hline \multirow[t]{5}{*}{ Black tea $($ mean $\pm \mathrm{SD})$} & Number of samples & 12 & 13 & 14 & 17 & 1 & 6 \\
\hline & $\mathrm{Mn}[\mathrm{mg} / \mathrm{kg}]$ & $1094 \pm 460$ & $972 \pm 448$ & $788 \pm 152$ & $751 \pm 185$ & $709 \pm 14$ & $718 \pm 232$ \\
\hline & $\mathrm{Cu}[\mathrm{mg} / \mathrm{kg}]$ & $21.3 \pm 6.9$ & $29.9 \pm 13.0$ & $16.5 \pm 3.9$ & $18.1 \pm 6.9$ & $14.34 \pm 0.49$ & $31.3 \pm 11.2$ \\
\hline & $\mathrm{Zn}[\mathrm{mg} / \mathrm{kg}]$ & $21.8 \pm 5.1$ & $44.6 \pm 12.9$ & $129 \pm 13$ & $65.7 \pm 31.3$ & $25.39 \pm 0.59$ & $52.6 \pm 16.8$ \\
\hline & $\mathrm{Cd}[\mu \mathrm{g} / \mathrm{kg}]$ & $31.3 \pm 18.4$ & - & $2.3 \pm 0.4$ & $1.1 \pm 0.5$ & $0.89 \pm 0.10$ & $426 \pm 506^{\mathrm{b}}$ \\
\hline
\end{tabular}

${ }^{\mathrm{a}}$ In this publication, results were given for each sample individually; means and SD were calculated by the authors of this work for the purpose of comparison

${ }^{\mathrm{b}}$ For $\mathrm{Cd}$, the number of samples was 20

It can be noticed that tea is a major source of manganese in the diet, while intake of other elements is negligible.

Since cadmium is considered a toxic element, there is no RDI defined for it. Cadmium content in the samples can be compared with the upper allowed level of this element in tea, which was established by ordinance of the Health Minister of Poland [12] and equals $0.10 \mathrm{mg} / \mathrm{kg}$ of dry material. It can be noticed from Table 3 that only in three samples (denoted 7, 8, and 24) was this level exceeded.

\section{Comparison with Other Types of Teas}

In separate studies, other types of tea, and similar beverages, were examined. Schunk et al. [13] analyzed Brazilian herbal teas (chamomile, lemongrass, fennel, and yerba mate). In that report, the copper concentration varied from $0.19 \pm 0.05$ to $0.43 \pm 0.07 \mu \mathrm{g} / \mathrm{g}$ while the levels of cadmium were much lower-between $0.03 \pm 0.01$ and $0.05 \pm 0.01 \mu \mathrm{g} / \mathrm{g}$. The highest Mn concentration was found to be $53.45 \pm 7.07 \mu \mathrm{g} /$ g. Results for copper and cadmium overlapped with those obtained in our work, but the content of manganese was much lower.

Rusinek-Prystupa et al. [14] examined teas containing yerba mate and rooibos. For both these groups, the concentration of $\mathrm{Zn}$ varied from 7.19 to $106 \mathrm{mg} / \mathrm{kg}$ and concentration of $\mathrm{Cu}$ was in a range from 1.98 to $14.05 \mathrm{mg} / \mathrm{kg}$ (being much lower for rooibos than for yerba mate). These values are in line with our results, with copper content being somewhat lower in rooibos than in ordinary tea. Manganese in yerba mate was present in the concentration from 269 to $2261 \mathrm{mg} / \mathrm{kg}$ which is again similar to the results of this work for green and black tea. However, the values found in rooibos were much lower (1.980-3.363 mg/kg).

Brzezicha-Cirocka et al. [15] analyzed eight types of fruit teas. Among all these groups, the concentrations were in a
Table 6 Estimated intakes of the elements from tea compared to recommendations

\begin{tabular}{|c|c|c|c|c|c|c|}
\hline \multirow[t]{2}{*}{ Element } & \multirow[t]{2}{*}{ Extraction degree [\%] } & \multirow[t]{2}{*}{$\begin{array}{l}\text { Calculated daily } \\
\text { intake }[\mathrm{mg} / \text { day }]\end{array}$} & \multicolumn{2}{|c|}{$\begin{array}{l}\text { Reference daily intake } \\
{[\mathrm{mg} / \text { day }][10]}\end{array}$} & \multicolumn{2}{|c|}{$\begin{array}{l}\text { Population reference } \\
\text { intake [mg/day] [11] }\end{array}$} \\
\hline & & & Male & Female & Male & Female \\
\hline \multicolumn{7}{|l|}{ Black tea } \\
\hline $\mathrm{Mn}$ & 28.9 & 1.42 & 2.3 & 1.8 & $1-10$ & $1-10$ \\
\hline $\mathrm{Zn}$ & 32.5 & 0.032 & 11 & 8 & 9.5 & 7 \\
\hline $\mathrm{Cu}$ & 22.7 & 0.022 & 0.9 & 0.9 & 1.1 & 1.1 \\
\hline \multicolumn{7}{|c|}{ Green tea } \\
\hline $\mathrm{Mn}$ & 30.6 & 1.12 & 2.3 & 1.8 & $1-10$ & $1-10$ \\
\hline $\mathrm{Zn}$ & 36.1 & 0.035 & 11 & 8 & 9.5 & 7 \\
\hline $\mathrm{Cu}$ & 22.6 & 0.017 & 0.9 & 0.9 & 1.1 & 1.1 \\
\hline
\end{tabular}


range of $15-30 \mathrm{mg} / \mathrm{kg}$ for $\mathrm{Cu}, 130-770 \mathrm{mg} / \mathrm{kg}$ for $\mathrm{Mn}$, and $3.8-15 \mathrm{mg} / \mathrm{kg}$ for $\mathrm{Zn}$. These values are, in general, comparable with those found by us in green or black teas (with our results being slightly higher).

\section{Limitation of the Study}

Currently, a large selection of white and red teas is available on the Polish market. Their lower consumption is implicated not only by their relatively higher prices but also by the nutritional habits of Polish consumers. On the other hand, it is well known that white teas have rich chemical composition (including the highest polyphenol content among all teas and therefore strong antioxidant activity). Similarly, it is believed that red teas also exert a variety of biological functions. For this reason, it is important to examine such teas, paying special attention to trace elements as well as other ingredients with favorable properties in human diet - in order to convince consumers to drink them more often. Small number of such teas examined in our study is its limitation and deserves next research particularly focused on white and red teas as possible candidates for potent functional food.

\section{Conclusions}

In black teas, $\mathrm{Mn} / \mathrm{Cd}$ ratio was found to be significantly higher vs. green or other teas, while $\mathrm{Cd}$ concentration was lower vs. other teas. Moreover, $\mathrm{Zn} / \mathrm{Cu}$ and $\mathrm{Cu} / \mathrm{Cd}$ ratios were, respectively, lower and higher when comparing black teas with other teas. This differentiation can be caused by the fermentation process during black tea production. Our results partly agree with the reports of other researchers; however, some differences can be noticed. In particular, zinc content in black tea as well as cadmium content in black and green teas was found to be much lower than reported by other authors. Very high content of manganese in two samples of black teas from Kenya was observed. Tea is a major dietary source of manganese while the intake of other elements is negligible. In three samples, content of cadmium was found to be higher than allowed by regulations of the Health Minister of Poland.

Acknowledgements The authors would like to acknowledge Prof. J.W. Mietelski from the Nuclear Physics Institute (Cracow, Poland) for the possibility of using the wet digestion system in his laboratory.

\section{Compliance with Ethical Standards}

Conflict of Interest The authors declare that they have no conflict of interest.

Open Access This article is distributed under the terms of the Creative Commons Attribution 4.0 International License (http:// creativecommons.org/licenses/by/4.0/), which permits unrestricted use, distribution, and reproduction in any medium, provided you give appropriate credit to the original author(s) and the source, provide a link to the Creative Commons license, and indicate if changes were made.

\section{References}

1. Street R, Száková J, Drábek O, Mládková L (2006) The status of micronutrients $(\mathrm{Cu}, \mathrm{Fe}, \mathrm{Mn}, \mathrm{Zn})$ in tea and tea infusions in selected samples imported to the Czech Republic. Czech J Food Sci 24:6271

2. Srividhya B, Subramanian R, Raj V (2011) Determination of lead, managanese, copper, zinc, cadmium, nickel and chromium in tea leaves. Int J Pharm Pharm Sci 3:16-17

3. Ashraf W, Mian AA (2008) Levels of selected heavy metals in black tea varieties consumed in Saudi Arabia. Bull Environ Contam Toxicol 81:101-104

4. Narin I, Colak H, Turkoglu O, Soylak M, Dogan M (2004) Heavy metals in black tea samples produced in Turkey. Bull Environ Contam Toxicol 72:844-849

5. Gajewska R, Nabrzyski M, Ganowiak Z, Cybulski M, Kułakowska D (2000) The content of selected mineral nutrients in green and black tea. Rocz Panstw Zakl Hig 51(3):251-258

6. Marcos A, Fisher A, Rea G, Hill SJ (1998) Preliminary study using trace element concentrations and a chemometrics approach to determine the geographical origin of tea. J Anal At Spectrom 13(6): 521-525

7. McKenzie J, Jurado J, de Pablos F (2010) Characterisation of tea leaves according to their total mineral content by means of probabilistic neural networks. Food Chem 123:859-864

8. Xie M, Von Bohlen A, Klockenkämper R, Jian X, Günther K (1998) Multielement analysis of Chinese tea (Camellia sinensis) by total-reflection X-ray fluorescence. Z Lebensm Unters Forsch A 207:31-38

9. Malik J, Szakova J, Drabek O, Balik J, Kokoska L (2008) Determination of certain micro and macroelements in plant stimulants and their infusions. Food Chem 111:520-525

10. Food and Nutrition Board, Institute of Medicine (2001) Intakes for vitamin $\mathrm{A}$, vitamin $\mathrm{K}$, arsenic, boron, chromium, copper, iodine, iron, manganese, molybdenum, nickel, silicon, vanadium, and zinc. National Academy Press, Washington, D.C.

11. Nutrient and energy intakes for the European Community. Reports of the Scientific Committee for Food (1993) Thirty-first series. Published by the Commission of the European Communities, Directorate-General Telecommunications, Information Industries and Innovation, Luxembourg. Pp. 193-214

12. Health Minister of Poland (2003) Ordinance of Health Minister of Poland regarding the maximum levels of chemical and biological contaminants which can be found in food, food components, permitted additives, reprocessing-auxiliary additives or on the surface of food. Dz.U. [Journal of Laws] from 2003, No. 37, item 326:2415

13. Schunk FPT, Kalil IC, Pimentel-Schmitt EF, Lenz D, De Andrade TU (2016) ICP-OES and micronucleus test to evaluate heavy metal contamination in commercially available Brazilian herbal teas. Biol Trace Elem Res 172:258-265

14. Rusinek-Prystupa E, Marzec Z, Sembratowicz I, Samolińska W, Kiczorowska B, Kwiecień M (2016) Content of selected minerals and active ingredients in teas containing yerba mate and rooibos. Biol Trace Elem Res 172:266-275

15. Brzezicha-Cirocka J, Grembecka M, Jezusek M, Szefer P (2015) Ocena zawartości wybranych mikropierwiastków w herbatach owocowych [Evaluation of consumption of microelements in popular fruit teas]. Bromat Chem Toksykol 48:274-277 